Jurnal Interpretasi Hukum |ISSN: 2746-5047

Vol. 2, No. 2 - Agustus 2021, Hal.397-402 | Tersedia online di https://www.ejournal.warmadewa.ac.id/index.php/juinhum DOI : https://doi.org/10.22225/juinhum.2.2.3448.397-402

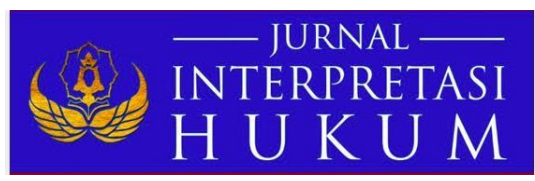

\title{
PERLINDUNGAN HUKUM TERHADAP PEMEGANG MEREK CLOTHING
}

\author{
I Made Agus Angga Kusuma Putra, Anak Agung Istri Agung \& Desak Gde Dwi Arini \\ Fakultas Hukum Universitas Warmadewa, Denpasar-Bali, Indonesia \\ anggakusumaa05@yahoo.com,notistria@yahoo.com, desakarini66@gmail.co.id
}

\begin{abstract}
Abstrak
Merek merupakan salah satu hak kekayaan intelektual yang paling banyak disengketakan. Keuntungan yang diperoleh dengan jalan pintas membuka peluang terjadinya peristiwa pemalsuan merek yaitu dengan cara melanggar etika bisnis, norma, dan hukum pastinya tidak membuat perdagangan menjadi baik dan memperburuk citra sebagai pelangar HKI. Adapun tujuan penelitian ini adalah untuk mengkaji bentuk perlindungan hukum terhadap pemegang merek clothing yang terdaftar dan menganalisa akibat hukum bagi pelaku usaha yang memasarkan merek clothing tanpa adanya ijin. Penelitian ini menggunakan metode penelitian hukum normatif, dengan menggunakan pendektan perundang-undangan. UndangUndang Nomor 20 Tahun 2016 dan Undang-Undang Nomor 5 Tahun 1999 sumber untuk mengetahui sanksi pidana dan juga sanksi perdata terhadap pelaku usaha yang menggunakan merek tanpa adanya ijin. Hasil penelitian ini menunjukan bentuk perlindungan hukum terhadap pemegang merek yang terdaftar berupa hak eksklusif yang diberikan oleh negara kepada pemilik merek yang terdaftar. Akibat hukum bagi pelaku usaha yang memasarkan merek tanpa adanya ijin dapat dikenai sanksi sebagai berikut, dalam pasal 382bis KUH Pidana juga dapat dikenakan sanksi yaitu perbuatan materil diancam hukuman penjara paling lama satu tahun dan denda setinggi-tinggi nya sembilan ratus juta rupiah.
\end{abstract}

Kata Kunci: Merek, Perlindungan Hukum, Persaingan Usaha.

\begin{abstract}
Trademarks are one of the most disputed intellectual property rights. The number of brand counterfeiting events conducted to gain profit by shortcuts, namely by violating business ethics, norms, and laws certainly do not make trade good and worsen the image as a violation of IPR. The purposes of this research are to examine the form of legal protection against registered clothing brand holders and to analyze the legal consequences for businesses that market clothing brands without a license? This research uses normative legal research methods by using statutory approach. Law No. 20 of 2016 and Law No. 5 of 1999 source to know criminal sanctions and also civil sanctions against businesses that use the brand without a permit. The results of this study show a form of legal protection against registered brand holders in the form of exclusive rights granted by the state to registered brand owners. Legal consequences for businesses that market brands without a license can be penalized as follows, in article 382 bis criminal code can also be penalized i.e. material acts are threatened with a maximum prison sentence of one year and a fine as high as nine hundred million rupiah.
\end{abstract}

Keywords: Business Competition, Legal Protection, Trademarks

\section{PENDAhUluAN}

Peristiwa terjadinya pemalsuan merek pastinya tidak membuat perdagangan menjadi baik dan memperburuk citra sebagai pelanggar HKI. Membahas tentang perlindungan hukum atas merek menjadi sangat menarik untuk dibahas, dimana dunia sampai saat ini berkembang dengan pesat dan merek memiliki peran yan sangat penting untuk diperhitungkan khususnya untuk proses perdagangan barang dan jasa diperdagangan bebas saat ini (Usman, 2003). Muhadjr Effendi (2008:252) menyebutkan salah satu cabang HKI yang memegang peran penting adalah merek. Merek ialah tanda yang digunakan atau dikenakan oleh pengusaha pada barang-barang yang dihasilkan sebagai tanda nama atau pengenal merek tersebut. Pengusaha-pengusaha baru tidak mendaftarkan merek pada produk yang diproduksinya, membuat merek tersebut tidak mendapatkan perlindungan hukum, sehingga apabila terjadi masalah atau pelanggaran HKI, pemilik merek tidak bisa membawa kasusnya ke jalur hukum (Jened, 2015). 
Merek yang telah terdaftar dilindungi oleh hukum berdasarkan pada Pasal 35 ayat (1) undang-undang tersebut menyebutkan bahwa perlindungan hukum terhadap merek terdaftar paling lama 10 tahun. Pengaturan yang demikian dimaksudkan agar para pemilik merek dapat disiplin, patuh serta taat pada peraturan merek yang berlaku demi keteraturan dan kelancaran dalam perdagangan untuk menciptakan kedamaian dalam masyarakat (Dewi, 2019). Pelanggaran merek umumnya dilakukan terhadap merek-merek terkenal salah satunya yaitu merek "Hiztory Store" di Denpasar. Casavera (2009) menyebutkan bahwa usaha pelanggaran merek merupakan suatu tindakan atau usaha yang dilakukan untuk memperoleh keuntungan dengan jalan pintas, yaitu dengan cara yang melanggar etika bisnis, norma, kesusilaan, dan hukum. Pengaturan yuridis yang tegas dalam Undang-Undang Merek membuat para pemilik merek sadar hukum dan peduli akan pentingnya pengembangan ekuitas merek, dan akan berupaya mendaftarkan mereknya untuk mendapatkan proteksi hokum, pihak-pihak tertentu yang bertikad tidak baik menempuh jalan pintas dengan melakukan peniruan atas merek yang telah terdaftar.

Persaingan dalam memiliki brand atau merek sendiri membuat beberapa oknum dengan seenaknya meniru atau bahkan memaikai merek orang lain. Hal ini juga berimbas pada merek asing yang terkenal di Indonesia, oleh karenanya perlu adanya perlindungan hukum terhadap merek terkenal asing di Indonesia (Kurniawan, 2019). Implementasi Undang-Undang Nomor. 20 Tahun 2016 Tentang Hak Merek Terhadap Clothing menjelaskan bahwa merek clothing yang telah terdaftar mendapatkan perlindungan hak selama 10 Tahun (Saputra, et al 2018). Kemudian peneliti memutuskan untuk mengkaji penelitian ini dengan untuk menganalisis bentuk perlindungan hukum terhadap pemegang merek clothing yang terdaftar dan menelaah akibat hukum bagi pelaku usaha yang memasarkan merek clothing tanpa adanya ijin.

\section{METODE PENELITIAN}

Metode penelitian yang digunakan dalam penelitian ini adalah metode hukum normatif dengan pendekatan perundangan-undangan, dengan menganalisis undang-undang dan regulasi mengenai hukum. Adapun beberapa sumber bahan hukum primer dan sekunder yang digunakan dalam penelitian yaitu "Undang-Undang Dasar Negara Republik Indonesia Tahun 1945, Kitab Undang-Undang Hukum Pidana, Kitab Undang-Undang Hukum Perdata, Undang-Undang Nomor 20 Tahun 2016 Tentang Merek dan Indikasi Geografis, Undang-Undang Nomor 5 Tahun 1999 Tentang Persaingan Usaha, serta jurnal-jurnal dan literatur yang terkait dengan penelitian ini." Teknik pengumpulan bahan hukum yang digunakan yaitu studi kepustakaan mengenai perlindungan hukum terhadap pemegang merek clothing yang terdaftar.

\section{HASIL DAN PEMBAHASAN}

\section{Bentuk Perlindungan Hukum Terhadap Pemegang Merek Clothing yang Terdaftar}

Menurut Tim Lindsey (2002) hak merek berfungsi sebagai suatu monopoli karena hanya pemilik merek yang dapat menggunakan merek tersebut. Hak merek bukan merupakan monopoli mutlak karena apabila jangka waktu perlindungan merek telah habis dan pemilik merek tidak memperjang waktu perlindungan tersebut, maka pihak lain dapat menggunakannya. Hak atas merek dapat dipertahankan terhadapa siapapun juga, pihak yang tidak berhak tidak bisa menggunakan merek sebagai hak eksklusif. Suatu merek menjadi hak yang semata-mata diperuntukkan bagi pemilik merek atau pihak lain yan diperbolehkan memanfaatkan hak tersebut dengan ijin pemilik merek.

Hak merek yang dimiliki oleh pemiliknya akan menimbulkan hak ekonomi karena merupakan hak eksklusif, sehingga hanya pemilik merek tersebut saja yang berhak atas hak ekonomi dari suatu merek. Hak ekonomi adalah suatu hak untuk memperoleh keuntungan ekonomi atas kekayaan intelektual. Hak ekonomi yang didapatkan bisa berupa keuntungan sejumlah uang yang diperoleh karena penggunaan merek oleh pemilik atau pihak lain yang menggunakan merek berdasar atas lisensi. Hak ekonomi pada merek terbatas pada tiga jenis yaitu lisensi merek dagang, penggunaan sendiri, penggunaan melalui lisensi merek jasa tanpa 
variasi lain (Lindsey, 2002). Pentingnya perlindungan hukum atas suatu merek bagi pemiliknya untuk mendapatkan perlindungan atas tindakan pelanggaran merek yang dilakukan oleh pihak lain. Negara dapat memberikan hak atas merek kepada seseorang apabila sudah mendaftarkan mereknya dan dapat membuktikan dengan adanya kepemilikan sertifikat merek, berdasarkan pasal 3 UU Merek, menjelaskan "'Hak atas merek adalah hak ekslusif yang diberikan oleh negara kepada pemilik merek yang terdaftar dalam Daftar Umum Merek untuk jangka waktu tertentu dengan menggunakan sendiri merek tersebut atau memberikan izin kepada pihak lain untuk menggunakannya".

Pemegang merek berhak mendapatkan perlindungan berupa pendaftaran serta perlindungan dalam wujud gugatan ganti rugi (dan gugatan pembatalan merek) maupun dalam bentuk pidana melalui aparat penegak hukumnya. Penyelesaian hukum melalui instrumen hukum perdata bisa dilakukan melalui pengadilan (litigasi) dengan gugatan ganti kerugian tersebut dan menghentikan seluruh perbuatan membuat, memakai, menjual, dan/atau mengedarkan barang-barang yang diberi hak merek, ataupun diluar pengadilan (non litigasi) yang memungkinkan para pihak bisa merampungkan sengketa tadi melalui arbitrase atau cara lain penyelesaian sengketa (ADR) dengan menggunakan negoisasi, mediasi dan konsoliasi. Pasal 72 ayat (1) Undang-Undang Merek menjelaskan, "merek memberikan hak kepada pemilik merek terdaftar untuk mengajukan gugatan terhadap orang atau badan hukum yang secara tanpa hak menggunakan merek yang mempunyai persamaan pada pokoknya atau keseluruhan dengan mereknya".

Perlindungan merek diatur dalam pasal 3 Undang-Undang No. 20 Tahun 2016 Tentang Merek dan Indikasi Georafis yaitu "Hak atas merek diperoleh setelah merek tersebut terdaftar". Terdaftar artinya telah melalui tahapan permohonan dengan proses pemeriksaan formalitas, proses pengumuman dan juga proses pemeriksaan subtantif serta telah memperoleh persetujuan menteri untuk menerbitkan sertifikat. Dikutip dari (Satjipto Rahardjo, 2000:53), "Perlindungan hukum harus melihat tahapan, yakni perlindungan hukum lahir dari suatu ketentuan hukum dan segala peraturan hukum yang diberikan oleh masyarakat, dimana merupakan kesepakatan dari masyarakat untuk mengatur hubungan perilaku antar anggota lainnya dan antara perseorangan yang dianggap mewakili kepentingan masyarakat".

Perkembangan pelanggaran merek telah berkembang menuju tingkat yang lebih tinggi dan canggih, yang disebut dengan passing off (pemboncengan reputasi). Dalam keputusan hukum Indonesia, istilah passing off ini belum dikenal, sehingga istilahnya pun secara keseluruhan masih asing. Istilah passing off dikenal dalam sistem common law. Sistem hukum common law pemonceng merek (passing off) adalah suatu tindakan persaingan dengan cara tidak sehat (unfair competition) sehingga akan mengakibatkan pemilik merek yang telah berusaha mendaftarkan merek tersebut sesuai dengan prosedur akan mengalami kerugian yang disebabkan oleh pihak yang dengan sengaja berlaku curang turut membonceng atau mendompleng merek miliknya untuk mendapatkan keuntungan finansial.

Hukum merek yang berlaku di Negara Indonesia memberikan penjelsan mengenai ukuran merek di kaitkan merek terkenal (well known mark) dapat dilihat pada bagian penjelasan Undang-Undang Merek Nomor 20 Tahun 2016 Pasal 21 Ayat (1) huruf b yaitu "permohonan ditolak jika merek tersebut mempunyai persamaan pada pokoknya atau keseluruhannya dengan merek terkenal milik pihak lain untuk barang dan/atau jasa sejenis".

\section{Akibat Hukum Bagi Pelaku Usaha yang Memasarkan Merek Clothing Tanpa Adanya Ijin}

Menurut Sudarga Gautama (1993) sebuah merek dapat disebut merek apabila memenuhi syarat mutlak berupa adanya daya pembeda yang cukup (capable of distinguishing). Maksudnya tanda yang dipakai tersebut mempunyai kekuataan untuk membedakan barang atau jasa yang diproduksi sesuatu perusahaan dari perusahaan lain. Untuk mempunyai daya pemebeda ini, maka merek itu harus dapat memberikan penentuan pada barang atau jasa bersangkutan.

Ketentuan mengenai merek yang tidak dapat didaftarkan dan ditolak dikutip dari Pasal 20 Undang-Undang Merek, "Merek yang tidak dapat didaftarkan apabila mengandung salah 
satu unsur: (a) Bertentangan dengan ideologi negara, peraturan perundang-undangan, moralitas, agama, kesusilaan atau ketertiban umum; (b) Sama dengan, berkaitan dengan, atau hanya menyebut barang dan/atau jasa yang dimohonkan pendaftarannya; (c) Memuat unsur yang dapat menyesatkan masyarakat tentang asal, kualitas, jenis, ukuran, macam, tujuan penggunaan barang dan/atau jasa yang sejenis; (d) Membuat keterangan yang tidak sesuai dengan kualitas, manfaat, atau khasiat dari barang dan atau jasa yang diproduksi; (e) Tidak mempunyai daya pembeda dan/atau; (f) Merupakan nama umum dan/atau lambang milik umum"

Permohonan terhadap suatu merek dapat ditolak jika merek tersebut mempunyai persmaan pada pokoknya atau keseluruhannya berdasarkan pasal 21 Undang-Undang Merek, "(a) Merek terdaftar milik pihak lain atau dimohonkan lebih dahulu oleh pihak lain untuk barang dan/atau jasa sejenis; (b) Merek terkenal milik pihak lain untuk barang dan/atau jasa sejenis; (c) Merek terkenal milik pihak lain untuk barang dan/atau jasa tidak sejenis yang memenuhi persyaratan tertentu atau; (d) Indiksi geografis terdaftar; (e) Merupakan atau menyerupai nama atau singkatan nama orang terkenal, foto, atau nama badan hukum yang dimiliki orang lain, kecuali atas persetujuan tertulis dari yang berhak; (f) Merupakan tiruan atau menyerupai nama atau singkatan nama, bendera, lambang, atau simbol atau emblem suatu negara atau lembaga nasional maupun internasional kecuali atas persetujuan tertulis dari pihak yang berwenang; (g) Merupakan tiruan atau menyerupai tanda atau cap atau stempel resmi yang digunakan oleh negara atau lembaga pemerintah, kecuali atas persetujuan tertulis dari pihak yang berwenang; (h) Permohonan ditolak jika diajukan oleh pemohon yang beritikad tidak baik."

Berdasarkan penjelasan sebelumnya, suatu merek dapat diakui dan dikategorikan sebagai merek apabila merek tersebut, “ (a) Mempunyai fungsi pembeda; (b) Merupakan tanda pada barang dagang atau jasa (unsur-unsur gambar, logo, nama, kata, huruf, angka, susunan warna, dalam bentuk 2 (dua) dimensi dan/atau 3 (tiga) dimensi, suara, hologram, atau kombinasi dari 2 (dua) atau kombinasi unsur-unsur tersebut; (c) Tidak memenuhi unsur-unsur yang bertentangan dengan ideologi negara, peraturan perundang-undangan, moralitas, agama, kesusilaan, atau ketertiban umum; (d) Bukan menjadi milik umum; (e) Tidak merupakan keterangan atau berkaitan dengan barang atau jasa yang dimohonkan pendaftarannya."

Dikutip dari Kansil (1990) jika suatu permohonan pendaftaran merek tidak memenuhi syarat-syarat yang ditentukan, maka kantor milik perindustrian memberitahukan secara tertulis kepada pemohon agar supaya permohonan memenuhi syarat-syarat tertentu atau menarik kembali permohonannya dalam waktu yang ditentukan oleh Kantor Milik Perindustrian. Pasal 20 Undang-Undang Merek menetapkan bahwa dalam hal pemeriksaan melaporkan hasil pemeriksaan subtantif bahwa permohonan dapat disetujui untuk didaftar, maka atas persetujuan Dirjen, permohonan tersebut diumumkan dalam Berita Resmi Merek (BRM). Sebaliknya jika pemeriksa melaporkan hasil pemeriksaan subtantif bahwa permohonan tidak dapat didaftar atau ditolak, maka atas persetujuan Dirjen, hal tersebut diberitahukan secara tertulis kepada pemohon atau kuasanya dengan menyebutkan alasannya.

Untuk dapat membedakan antara merek yang tidak dapat didaftarkan dengan merek yang ditolak pendaftarannya yaitu melihat dari pihak yang dirugikan. Dengan memperhatikan hal tersbut, maka dapat disimpulkan bahwa suatu merek yang memiliki kemungkinan dapat memberikan kerugian kepada masyarakat umum, maka merek tersebut tidak dapat didaftarkan. Namun jika merek tersebut hanya merugikan pihak-pihak tertentu saja, maka merek tersebut akan ditolak ditolak pendaftarannya. Lebih sederahananya, suatu merek yang tidak dapat didaftarkan yaitu merek yang tidak layak dijadikan merek, sedangkan merek yang ditolak yaitu merek yang merugikan pihak lain

Pelaku usaha merek Clothing yang tidak mendaftarkan mereknya, maka merek tersebut tidak memiliki perlindungan hukum. Riswandi \& Syamsudin (2005:82) menyebutkan. "Adanya pelanggaran merek yang dilakukan oleh pihak-pihak yang beritikad tidak baik dan tidak bertanggung jawab terhadap merek terkenal yang dilanggarnya akan menyebabkan kerugian, sehingga pemegang hak atas merek terkenal akan menempuh jalur hukum untuk menyelesaikan 
kasus pelanggaran merek agar pelaku pelanggaran merek tidak akan lagi memakai merek yang menyerupai pada pokoknya atau keseluruhannya dari merek terkenal atau bahkan menghentikan produksinya. Perbuatan pelangggaran merek selain diatur di dalam Undang-Undang Merek, juga dapat dikenai sanksi yang dapat ditinjau dari hukum pidana, perdata, maupun adminitrasi."

Apabila seseorang menggunakan merek tanpa hak, maka akan dapat digugat berdasarkan perbuatan melanggar hukum (pasal 1365 KUHPerdata) yaitu "Tiap perbuatan melanggar hukum, yang membawa kerugian kepada orang lain, mewajibkan orang yang karena salahnya menerbitkan kerugian itu, mengganti kerugian tersebut".

Akibat hukum apabila pihak yang menemukan merek pertama kali belum mendaftarkan mereknya, maka pihak lain dapat mendaftarkan merek dengan nama yang sama dan pihak tersebut yang akan mendapatkan perlindungan hukum yang sah dan apabila hal tersebut terjadi maka pihak pertama yang menemukan merek akan merasa sangat dirugikan namun tidak bisa melakukan tindakan hukum karena memang belum terdaftar mereknya.

Pihak yang menggunakan dan meniru merek yang telah didaftarkan sebelumnya oleh pihak pemilik hak atas merek dapat diajukan melalui jalur hukum berupa sanksi pidana sebagaimana pengaturan dalam Pasal 200 Ayat (2) Undang-Undang Merek dan Indikasi Geografis menyatakan bahwa setiap orang yang tidak memiliki hak dalam penggunaan merek yang mempunyai persamaan pada pokoknya dengan merek terdaftar milik pihak lain untuk barang atau jasa sejenis yang diproduksi maupun diperdagangkan, akan dipidana dengan pidana penjara paling lama empat tahun dan/atau denda paling banyak dua miliar rupiah.

Pihak yang mengakibatkan kerugian bagi pemilik asli dari merek yang bersangkutan dapat mengajukan gugatan secara perdata melalui jalur litigasi. Pengaturan pada pasal 1365 KUHPerdata, mengatur bahwa pemilik asli merek dapat mengajukan gugatan kepada pengadilan yang berwenang yaitu pengadilan niaga, serta melalui jalur non litigasi. Untuk menyikapi barang bajakan atau barang palsu, dalam pasal 100 sampai pasal 102 UndangUndang Nomor 20 Tahun 2016 diatur mengenai ketentuan pidana terkait Merek dan Indikasi Geografis.

\section{SIMPULAN DAN SARAN}

\section{Simpulan}

Berdasaran penjelasan hasil penelitian di atas, dapat disimpulkan bahwa bentuk perlindungan hukum terhadap pemegang merek yang terdaftar, akan mendapatkan perlindungan hukum dengan dua cara yaitu perlindungan hukum preventif dan perlindungan hukum represif. Perlindungan hukum preventif ialah sebuah bentuk perlindungan yang mengarah pada tindakan yang bersifat pencegahan dan perlindungan hukum represif ialah pemberian sanksi secara tegas bagi pelaku pelanggaran merek sesuai dengan Undang-Undang Merek yang berlaku. Serta akibat hukum bagi pelaku usaha yang memasarkan merek tanpa ijin yaitu dalam ranah perdata dapat berupa ganti kerugian karena termasuk dalam tindakan melawan hukum dengan cara menggunakan hak merek tanpa mendapat persetujuan dari pemilik hak atas merek yang terdaftar, dan juga dapat dikategorikan pelanggaran Undang-Undang Merek yang memuat sanksi pidana, sesuai ketentuan pasal 382bis KUHP dan pasal100-102 Undang-Undang Nomor 20 Tahun 2016 tentang Merek dan Indikasi Geografis dengan memperdagangkan barang tiruan yang menggunakan merek terkenal atau terdaftar.

\section{Saran}

Melalui kajian ini peneliti ingin menyampaikan beberapa saran yang kiranya dapat membantu pemerintah dalam menetapkan keputusan mengenai pelanggaran terhadap pemegang merek clothing, yaitu sebagai berikut:

1. Kepada pemerintah (Drijen HKI) untuk memberikan sanksi yang tegas dan konsisten bagi pelaku pelanggaran merek sesuai dengan Undang-Undang Merek yang berlaku.

2. Kepada pelaku usaha untuk memperhatikan aturan hukum yang berlaku agar tidak ada lagi masyarakat yang dirugikan terhadap pelanggaran merek yang beredar dan di konsumsi oleh 
masyarakat, agar tidak ada lagi kecurangan dalam persaingan usaha tidak sehat dan tidak lagi memalsukan atau menjiplak merek terkenal yang dari segi kualitas jauh dari aslinya.

3. Kepada masyarakat agar lebih teliti dalam membeli dan menggunakan sebuah merek barang maupun jasa dapat memahami dan mengetahui perihal tentang pendaftaran merek supaya tidak dirugikan dengan pemakaian merek yang beredar di Indonesia yang mana merek dimaksud dibuat dengan melanggar aturan hukum yang berlaku dan didikasikan terdapat tindak pidana.

\section{DAFTAR PUSTAKA}

Casavera. (2009). 5 kasus sengketa merek di Indonesia. Graha Ilmu, Yogyakarta.

Dewi, C. G. (2019). Perlindungan Hukum. CV.Budi Utama, Yogyakarta.

Effendi, M. (2008). Kamus Besar Bahasa Indonesia. Balai Pustaka, Jakarta.

Gautama, S. (1989). Hukum merek Indonesia. Citra Aditya Bakti, Bandung.

Jened, R. (2015). Hukum Merek (Trademark Law) Dalam Globalisasi dan Integrasi Ekonomi. PT Kharisma Putra Utama, Jakarta.

Kansil, C. S. (1990). Hak milik intelektual: hak milik perindustrian dan hak cipta: paten, merek perusahaan, merek perniagaan, hak cipta. Bumi Aksara, Jakarta.

Kurniawan, R., \& Bustani, S. (2019). Perlindungan Hukum Terhadap Merek Terkenal Asing di Indonesia (Studi Kasus Putusan Mahkama Agung Nomor: 165/Pdt.Sus-Hki/2016 dan Putusan Mahkama Agung Nomor: 557K/Pdt.sus-HKI/2015). Jurnal Hukum Adigama, Vol.2(2).

Lindsey, T. (2002). Hak Kekyaan Intelektual Suatu Pengantar. Alumni, Bandung.

Rahardjo, S. (2000). Ilmu Hukum. Citra Aditya Bakti, Bandung.

Riswandi, B. A., \& Syamsudin, M. (2005). Hak kekayaan intelektual dan budaya hukum. Raja Grafindo Persada, Jakarta.

Saputra, P. A. Y., Windari, R. A., \& Adnyani, N. K. S. (2018). Implementasi Undang-Undang No 20 Tahun 2016 Tentang Hak Merek Terhadap Clothing Di Kota Singaraja. Jurnal Komunitas Yustisia, Vol.1(2).

Usman, R. (2003). Hukum atas Kekayaan Intelektual: Perlindungan dan Dimensi Hukumnya di Indonesia. Alumni, Bandung. 